\title{
NEUROPHARMACOLOGICAL EVALUATION OF SEDATIVE AND MUSCLE RELAXANT PROPERTIES OF RAPHANUS CAUDATUS IN ALBINO MICE
}

\author{
ISHRAT YOUNUS ${ }^{1}$, AFSHAN SIDDIQ ${ }^{2 *}$, SADIA GHOUSIA BAIG ${ }^{2}$, \\ SARAH JAMEEL KHAN ${ }^{1}$, BILQEES FATIMA', SHAGUFTA NESAR', \\ TAYYABA MUMTAZ ${ }^{3}$, SIDRA SIDDIQUE' ${ }^{1}$ and RIDA FATIMA ${ }^{1}$
}

\author{
'Faculty of Pharmacy, Hamdard University, Karachi, Pakistan \\ ${ }^{2}$ Department of Pharmacology, Faculty of Pharmacy and Pharmaceutical Sciences, \\ University of Karachi, Karachi, Pakistan \\ ${ }^{3}$ Department of Pharmacognosy, Faculty of Pharmacy, Ziauddin University, Karachi, \\ Pakistan
}

\begin{abstract}
In present days vegetables and fruits provided by nature are underutilized and underestimated. Raphanus caudatus is one of an ignored vegetable belonging to radish plant because it is not only underutilized by the population but also the researches had not focused to identify its phytochemical as well as pharmacological potential. The present study was designed with the aim to evaluate sedative and muscle relaxant properties of ethanol extract of Raphanus caudatus in a mouse model. In the current study, the effects of ethanol extract of Raphanus caudatus were observed on general performance and behavioral changes of mice. Moreover, sedative and muscle relaxant properties of the extract were evaluated at three different doses $(250,500 \mathrm{and} 1000 \mathrm{mg} / \mathrm{kg})$ in the mouse model using phenobarbitone induced sleeping time and rotarod test respectively. The extract at highest tested dose i.e. $1000 \mathrm{mg} / \mathrm{kg}$ produced significant $(\mathrm{p}<0.05)$ sedative action. However, the extract was observed to be lacking in muscle relaxant properties at any of tested dose in mice up to 60 days post-treatment. The study shows that ethanol extract of Raphanus caudatus possess sedative neuro-pharmacological potential and may possibly be used as a valuable source of bioactive constituents with psychosedative properties.
\end{abstract}

Keywords: Raphanus caudatus, ethanol extract, sedation, muscle relaxation

Vegetables are of great importance because they are not only used as food rather they also play a fundamental role in the prevention and treatment of different illnesses. They are a rich source of vitamins, minerals, amino acids, antioxidants and fibers thus they can be effectively used to build up and repair the body $(1,2)$. Particularly with reference to cruciferous vegetables, they have been well known for their striking cardioprotective, antimicrobial and anticarcinogenic effects. Various types of vegetables are cultivated at the diversified agro climate areas of Pakistan (3).

In the modern era, nature and natural resources are underutilized and underestimated especially by the young generation (4). This is the reason even leading to various illnesses along with micronutrient deficiencies (5). There is dire need to utilize natural- ly occurring vegetables as well as fruits for better health along with an active lifestyle.

Raphanus caudatus (family Brassicaceae) commonly known as Rat-tailed radish belonging to radish plant is considered as one of the ignored vegetable (6). This vegetable becomes available between the months of November to March. So far few studies have been reported regarding its pharmacological potential. Previously we reported substantial antidepressant activity of Raphanus caudatus in a mouse model (7).

Radish (Raphanus sativus) is well-identified for significant pharmacological potential (8) (Fig. 1). Hence, Raphanus caudatus was particularly selected to precisely identify its neuropharmacological potential on sedation and motor coordination by using rodent model.

\footnotetext{
* Corresponding author: e-mail: afshan@uok.edu.pk
} 


\section{EXPERIMENTAL}

\section{Material and methods}

Plant material

Fresh Raphanus caudatus pods were procured from a local market of Karachi, identified by Dr. Mohtashim (Associate Professor, Department of Pharmacognosy, University of Karachi). The specimen with voucher number: RSP-01-14/17 was submitted to Department of Pharmacognosy.

The plant material was air-dried for 7 days under shade and grinded with a mechanical grinder to obtain a powder.

\section{Extraction of plant material}

The dried plant material was extracted using ethanol (Merck, 97\%) in a ratio of $1: 50 \mathrm{w} / \mathrm{v}$ at a temperature of $60^{\circ} \mathrm{C}$ using soxhlet apparatus (HMFT-5/63, England) (9). The extraction process was carried out until exhaustion. After filtration, the extract was dried by Rotary Evaporator (Buchi).

\section{Study animals and grouping}

The neuropharmacological study was carried out on adult healthy albino male mice $(n=10$ each group) weighing $25 \pm 2 \mathrm{~g}$. The animals were placed for 7 days to acclimatize the laboratory conditions before starting the study. Standard conditions of temperature $\left(25 \pm 1^{\circ} \mathrm{C}\right)$, humidity $(60 \%)$ with $12 / 12$ $\mathrm{h}$ light and dark cycle were provided. The diet and water were provided ad libitum to all animals.

\section{Grouping and dosing}

The animals were indiscriminately distributed into five groups ( $\mathrm{n}=10$ each group). Ist and $2^{\text {nd }}$ groups were kept as Control and Standard provided with normal saline and diazepam $(1 \mathrm{mg} / \mathrm{kg}$, suspending in distilled water) respectively via the oral route. Three groups were kept as test groups, kept on ethanol extract of Raphanus caudatus (EERC) in doses of 250,500 and $1000 \mathrm{mg} / \mathrm{kg}$ respectively by using an orogastric tube (after dissolving in $1 \mathrm{~mL}$ of distilled water). The dosing was done once daily according to the bodyweight for a continuous 60 days. The doses for test groups were selected on the basis of Acute toxicity testing OECD guidelines 423 as mentioned in our previously reported study (10). All the neuropharmacological tests were conducted between 8 am to $4 \mathrm{pm}$.

\section{General performance of mice}

To observe the general performance of animals, skin ulceration, weekly average weight variation, feed intake hematuria, loss of hair, loss of activity, vomiting, diarrhea, edema, salivation, tremor, and aggressive behavior were noticed till the end of the experimental period.

\section{Gross behavioral activities}

Following tests were conducted to observe the effects of EERC on behavioral changes:

\section{Awareness and alertness test}

Control, as well as all tested groups of albino mice, was kept in wide-mouth glass jar separately for at least a period of $30 \mathrm{~min}$ to observe awareness, alertness and stereotype after 7, 15, 30 and 60 days of dosing of EERC.

\section{Mood test}

Normal saline and EERC treated groups were placed in home cage separately for at least a period

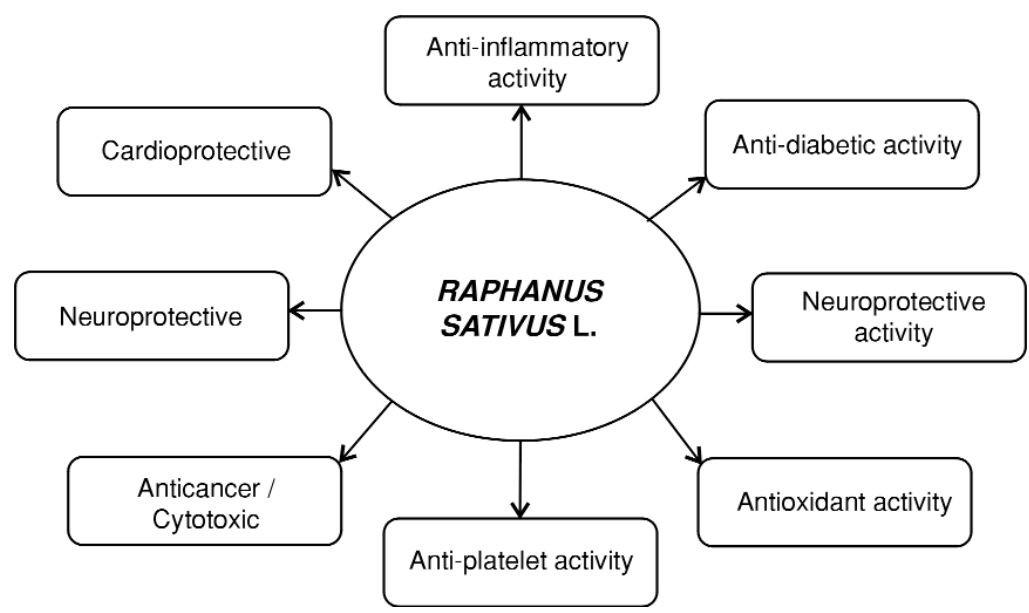

Figure 1. Pharmacological activities of Raphanus sativus L. 
of $30 \mathrm{~min}$ and observed the vocalization, restlessness and aggression after 7, 15, 30 and 60 days of dosing of EERC.

\section{View jar test}

Control and three groups of EERC were placed in view jars separately for at least a period of $01 \mathrm{~min}$ and noted the spontaneous activity, twitches and tremors after 7, 15, 30 and 60 days of dosing of EERC.

\section{View cage test}

Albino mice control and treated groups were placed in a viewing transparent cage separately for at least $30 \mathrm{~min}$ and observed the fearfulness, corneal reflex, light reflex and number of deaths after 7, 15, 30 and 60 days of dosing of EERC.

\section{Test for touch response}

Albino mice control and treated groups were placed in a home cage separately and observed the touch response and body movement after touching with the pencil at various portions of the body especially tail after 7, 15, 30 and 60 days of dosing of EERC.

\section{Test for pain response}

Control and treated animal groups were placed in a home cage separately and observed the pain response and sedation after touching tail after 7, 15, 30 and 60 days of dosing of EERC.

\section{Wire hanging test}

Stainless Steel Bars were used for Ibis purpose, mice control and treated groups were placed on Stainless Steel Bar separately with the help of forelimb or hind limb and observed the grip strength, body tone and limb tone 10 evaluate the motor or muscular function of the animal after 7, 15, 30 and 60 days of dosing of EERC.

\section{Righting reflex test}

Albino mice control and treated groups were placed on the surface on its back, if the animal remains in the same condition so the loss of righting reflex occurs and also observed the tonic-clooic and myoclonic seizures after 7, 15, 30 and 60 days of dosing of EERC.

\section{Home cage activity}

Control and treated mice groups were placed in a Home Cage separately for at least $30 \mathrm{~min}$ and observed the passivity, irritability and staggering gait after 7, 15, 30 and 60 days of dosing of EERC.

\section{Test for sedative activity}

Phenobarbitone stimulated sleeping test

In phenobarbitone stimulated sleeping time, sleep onset was assessed by change in time of drug administration and time of loss of righting reflex, while sleep duration was represented by time loss to recover from righting reflex (11).

On the day of testing, thirty minutes after giving saline, diazepam and EERC (250, 500 and 1000 $\mathrm{mg} / \mathrm{kg}$ ), animals of all groups were given phenobarbitone sodium $(40 \mathrm{mg} / \mathrm{kg})$ by intraperitoneal route, immediately after this each animal was kept under observation in an individual cage. The time taken for the loss of righting reflex (onset of action) and time to improve from righting reflex (duration of action) for each animal was recorded. The test was commenced on four different days of study i.e. $7,15,30$ and 60 of research.

\section{Test for muscle relaxant activity \\ Rota rod test}

The apparatus comprised of a base platform and a horizontal rod of iron $(30 \mathrm{~cm}$ length, $3 \mathrm{~cm}$ diameter), having a non-slippery surface. Mice were examined for their ability to hold the rod at the speed of $16 \mathrm{rpm}$ for $5 \mathrm{~min}$ trial. The animals were preselected through a learning period over 2 consecutive days before the test on their capacity to stay on the rod for $2 \mathrm{~min}$. On the test day $\left(7^{\text {th }}, 15^{\text {th }}, 30^{\text {th }}\right.$ and $60^{\text {th }}$ of saline, diazepam and EERC I, II, III administration), control, standard and test animals were individually placed on to the rotating rod for $5 \mathrm{~min}$. The "time period" during which mice remained on the rod was considered as the performance time (12).

\section{Statistical analysis}

The data analysis was conducted by SPSS-20 and results were mentioned as mean + S.E.M. One way ANOVA followed by post hoc Tukey's HSD test was employed in the present study with $\mathrm{p} \leq 0.05$ and $\mathrm{p} \leq 0.005$ as significant and highly significant respectively.

\section{RESULTS}

\section{General performance of mice}

The effects of EERC on general performance of mice are described in Table 1.

\section{Gross behavioral activities of mice}

The effects of EERC on gross behavioral activities are mentioned in Table 2. 
Table 1. Effect of EERC on general performance of animals.

\begin{tabular}{|c|c|c|c|c|c|}
\hline General effects & Time interval (days) & Control group & EERC I & EERC II & EERC III \\
\hline \multirow{4}{*}{$\begin{array}{c}\text { Skin } \\
\text { ulceration }\end{array}$} & $7^{\text {th }}$ & Nil & Nil & Nil & Nil \\
\hline & $15^{\text {th }}$ & Nil & Nil & Nil & Nil \\
\hline & $30^{\text {th }}$ & Nil & Nil & Nil & Nil \\
\hline & $60^{\text {th }}$ & Nil & Nil & Nil & Nil \\
\hline \multirow{4}{*}{$\begin{array}{l}\text { Average } \\
\text { weight } \\
\text { Variation } \\
(\mathrm{gm})\end{array}$} & $7^{\text {th }}$ & +15 & +13 & +40 & +10 \\
\hline & $15^{\text {th }}$ & +28 & +12 & +36 & +17 \\
\hline & $30^{\text {th }}$ & +31 & +13 & +51 & -50 \\
\hline & $60^{\text {th }}$ & +53 & +11 & +23 & -62 \\
\hline \multirow{4}{*}{$\begin{array}{l}\text { Feed } \\
\text { intake }\end{array}$} & $7^{\text {th }}$ & Normal & Normal & Normal & Normal \\
\hline & $15^{\text {th }}$ & Normal & Normal & Normal & Normal \\
\hline & $30^{\text {th }}$ & Normal & Normal & Normal & Normal \\
\hline & $60^{\text {th }}$ & Normal & Normal & Normal & Normal \\
\hline \multirow{4}{*}{ Hematuria } & $7^{\text {th }}$ & Nil & Nil & Nil & Nil \\
\hline & $15^{\text {th }}$ & Nil & Nil & Nil & Nil \\
\hline & $30^{\text {th }}$ & Nil & Nil & Nil & Nil \\
\hline & $60^{\text {th }}$ & Nil & Nil & Nil & Nil \\
\hline \multirow{4}{*}{$\begin{array}{l}\text { Loss of } \\
\text { hairs }\end{array}$} & $7^{\text {th }}$ & Nil & Nil & Nil & Nil \\
\hline & $15^{\text {th }}$ & Nil & Nil & Nil & Nil \\
\hline & $30^{\text {th }}$ & Nil & Nil & Nil & Nil \\
\hline & $60^{\text {th }}$ & Nil & Nil & Nil & Nil \\
\hline \multirow{4}{*}{$\begin{array}{l}\text { Loss of } \\
\text { activity }\end{array}$} & $7^{\text {th }}$ & Nil & Nil & Nil & Nil \\
\hline & $15^{\text {th }}$ & Nil & Nil & Nil & Nil \\
\hline & $30^{\text {th }}$ & Nil & Nil & Nil & Nil \\
\hline & $60^{\text {th }}$ & Nil & Nil & Nil & Nil \\
\hline \multirow{4}{*}{ Vomiting } & $7^{\text {th }}$ & Nil & Nil & Nil & Nil \\
\hline & $15^{\text {th }}$ & Nil & Nil & Nil & Nil \\
\hline & $30^{\text {th }}$ & Nil & Nil & Nil & Nil \\
\hline & $60^{\text {th }}$ & Nil & Nil & Nil & Nil \\
\hline \multirow{4}{*}{ Diarrhea } & $7^{\text {th }}$ & Nil & Nil & Nil & Nil \\
\hline & $15^{\text {th }}$ & Nil & Nil & Nil & Nil \\
\hline & $30^{\text {th }}$ & Nil & Nil & Nil & Nil \\
\hline & $60^{\text {th }}$ & Nil & Nil & Nil & Nil \\
\hline \multirow{4}{*}{ Edema } & $7^{\text {th }}$ & Nil & Nil & Nil & Nil \\
\hline & $15^{\text {th }}$ & Nil & Nil & Nil & Nil \\
\hline & $30^{\text {th }}$ & Nil & Nil & Nil & Nil \\
\hline & $60^{\text {th }}$ & Nil & Nil & Nil & Nil \\
\hline \multirow{4}{*}{ Salivation } & $7^{\text {th }}$ & Nil & Nil & Nil & Nil \\
\hline & $15^{\text {th }}$ & Nil & Nil & Nil & Nil \\
\hline & $30^{\text {th }}$ & Nil & Nil & Nil & Nil \\
\hline & $60^{\text {th }}$ & Nil & Nil & Nil & Nil \\
\hline \multirow{4}{*}{ Tremor } & $7^{\text {th }}$ & Nil & Nil & Nil & Nil \\
\hline & $15^{\text {th }}$ & Nil & Nil & Nil & Nil \\
\hline & $30^{\text {th }}$ & Nil & Nil & Nil & Nil \\
\hline & $60^{\text {th }}$ & Nil & Nil & Nil & Nil \\
\hline \multirow{4}{*}{$\begin{array}{l}\text { Aggressive } \\
\text { behaviour }\end{array}$} & $7^{\text {th }}$ & Nil & Nil & Nil & Nil \\
\hline & $15^{\text {th }}$ & Nil & Nil & Nil & Nil \\
\hline & $30^{\text {th }}$ & Nil & Nil & Nil & Nil \\
\hline & $60^{\text {th }}$ & Nil & Nil & Nil & Nil \\
\hline
\end{tabular}




\section{Sedative effect}

The effects of EERC and diazepam on sleep onset and sleep duration are depicted in Table 3 and 4 respectively. EERC at highest tested dose i.e. 1000 $\mathrm{mg} / \mathrm{kg}$ produced significant $(\mathrm{p}<0.05)$ sedative effect as compared to control as not only sleep onset was faster rather sleep duration was also increased.

\section{Muscle relaxant effect}

The effects of EERC and diazepam on muscle relaxation are depicted in Table 5. It is evident from the current data that EERC at any of tested dose did not produce any effect on motor coordination in the rotarod test. However, the standard drug diazepam exerted significant muscle relaxant effect indicated by an increment in the time duration spent on the rotarod.

\section{DISCUSSION}

It is well acknowledged that plants have enriched profile of bioactive constituents for example flavonoids, alkaloids, polysaccharides, coumarins, glycosides, lignans, saponins, polylines, thiophenes, proteins and polyphenolics (13). Raphanus caudatus in a previous study also revealed different bioactive constituents that include several glucosinolates, indoles, isothiocyanates, alkaloids, flavonoids, oxazolidine and thiocyanates (14). Similarly, flavonoids occurrence have also been reported in $\mathrm{R}$. caudatus $(15,16)$. Thus the plant can be targeted by the researchers for exact phytochemistry as well as its therapeutic potential.

In the present investigation, the sedative activity of EERC was evaluated by phenobarbitone

Table 2. Gross behavioral activities of EERC treated group.

\begin{tabular}{|c|c|c|}
\hline Tests & Activities & Effect of EERC \\
\hline \multirow{3}{*}{ Awareness and alertness test } & Awareness & With increment in dose it was increased \\
\hline & Alertness & With increment in dose it was increased \\
\hline & Stereotype & With increment in dose it was increased \\
\hline \multirow{3}{*}{ Mood test } & Mood & With increment in dose it was increased \\
\hline & Vocalization & With increment in dose it was increased \\
\hline & Aggression & With increment in dose it was increased \\
\hline \multirow{3}{*}{ View jar test } & Tremors & No effect at all tested doses \\
\hline & Twitches & No effect at all tested doses \\
\hline & Spontaneous activity & No effect at all tested doses \\
\hline \multirow{3}{*}{ Viewing cage test } & Fearfulness & No effect at all tested doses \\
\hline & Corneal reflex & No effect at all tested doses \\
\hline & Light reflex & No effect at all tested doses \\
\hline \multirow{2}{*}{$\begin{array}{c}\text { Touch response } \\
\text { test }\end{array}$} & Touch response & No effect at all tested doses \\
\hline & Body movement & No effect at all tested doses \\
\hline \multirow[t]{2}{*}{ Pain test } & Pain response & No effect at all tested doses \\
\hline & Sedation & With increment in dose it was increased \\
\hline \multirow{3}{*}{ Wire hanging test } & Grip strength & No effect at all tested doses \\
\hline & Body tone & No effect at all tested doses \\
\hline & Limb tone & No effect at all tested doses \\
\hline \multirow{3}{*}{ Righting reflex test } & Righting reflex & No effect at all tested doses \\
\hline & Tonic-clonic seizures & Absent at all tested doses \\
\hline & Myoclonic seizures & Absent at all tested doses \\
\hline \multirow{3}{*}{ Home cage activities test } & Passivity & With increment in dose it was increased \\
\hline & Irritability & Absent at all tested doses \\
\hline & Staggering Gait & Absent at all tested doses \\
\hline
\end{tabular}


induced sleep time. Sedation is the decrease of irritability that can be achieved by administration of drugs known as a sedative. These drugs are generally used to assist the surgery (17). Our results indicate that substantial sedative effect was observed at 1000 $\mathrm{mg} / \mathrm{kg}$ of EERC, designated by a prominent reduction in the time of onset of sleep as well as augmentation of sleep induced by phenobarbitone which was comparable to standard drug diazepam. Phenobarbitone is a hypnotic agent that induces hypnosis by increasing
GABA transmission. Substances with CNS depressive capability either reduce the time for onset of sleep or increase the length of sleep or both.

Currently available sedative-hypnotic agents are chemically heterogeneous groups among which benzodiazepine is the major group. Besides, other agents are also available such as barbiturates, carbamates, cyclic ethers and miscellaneous agents (zolpidem, zaleplon, Ramelteon etc.) (18). Similarly, in the case of plant source several bioactive con-

Table 3. Effect of ethanol extract of Raphanus caudatus and diazepam on the sleep onset in Phenobarbitone-induced sleeping time.

\begin{tabular}{|c|c|c|c|c|c|}
\hline \multirow{2}{*}{ Groups } & \multirow{2}{*}{ Treatment } & \multicolumn{4}{|c|}{ Sleep Onset $(\mathrm{min})$} \\
\cline { 3 - 6 } & & $7^{\text {th }}$ day & $15^{\text {th }}$ day & $30^{\text {th }}$ day & $60^{\text {th }}$ day \\
\hline Control & Normal saline $(1 \mathrm{~mL} / \mathrm{kg})$ & $40.4 \pm 2.18$ & $40.8 \pm 2.85$ & $40.2 \pm 1.07$ & $39.8 \pm 2.31$ \\
\hline Standard & Diazepam $(1 \mathrm{mg} / \mathrm{kg})$ & $22.2 \pm 1.07^{* *}$ & $19.8 \pm 0.58^{* *}$ & $17.2 \pm 0.37^{* *}$ & $13.6 \pm 0.4^{* *}$ \\
\hline Test group I & EERC $(250 \mathrm{mg} / \mathrm{kg})$ & $46.4 \pm 1.91$ & $47.9 \pm 1.31$ & $45.4 \pm 0.75$ & $42.4 \pm 1.17$ \\
\hline Test group II & EERC $(500 \mathrm{mg} / \mathrm{kg})$ & $33.2 \pm 2.06$ & $37.4 \pm 1.72$ & $33.3 \pm 1.74$ & $36.6 \pm 0.93$ \\
\hline Test group III & EERC $(1000 \mathrm{mg} / \mathrm{kg})$ & $26.4 \pm 1.21^{* *}$ & $21.6 \pm 1.5^{* *}$ & $16.9 \pm 1.14^{* *}$ & $12.6 \pm 0.75^{* *}$ \\
\hline
\end{tabular}

$\mathrm{n}=10$, values are mean \pm S.E.M, One-way ANOVA followed by post hoc Tukey HSD, $* \mathrm{p} \leq 0.05$ significant $\& * * \mathrm{p} \leq 0.005$ highly significant with respect to control. EERC: Ethanol extract of Raphanus caudatus

Table 4. Effect of ethanol extract of Raphanus caudatus and diazepam on the sleep duration in phenobarbitone-induced sleeping time.

\begin{tabular}{|c|c|c|c|c|c|}
\hline \multirow{2}{*}{ Groups } & \multirow{2}{*}{ Treatment } & \multicolumn{4}{|c|}{ Sleep duration $(\mathrm{min})$} \\
\cline { 3 - 6 } & & $7^{\text {th }}$ day & $15^{\text {th }}$ day & $30^{\text {th }}$ day & $60^{\text {th }}$ day \\
\hline Control & Normal saline $(1 \mathrm{~mL} / \mathrm{kg})$ & $56.4 \pm 2.54$ & $60 \pm 1.34$ & $52.6 \pm 1.21$ & $54.4 \pm 1.03$ \\
\hline Standard & Diazepam $(1 \mathrm{mg} / \mathrm{kg})$ & $168.2 \pm 3.44 * *$ & $181.4 \pm 5.19^{* *}$ & $179.4 \pm 5.05^{* *}$ & $176.6 \pm 4.72^{* *}$ \\
\hline Test group I & EERC $(250 \mathrm{mg} / \mathrm{kg})$ & $60.6 \pm 3.03$ & $55.2 \pm 1.8$ & $59.4 \pm 5.39$ & $51 \pm 0.84$ \\
\hline Test group II & EERC $(500 \mathrm{mg} / \mathrm{kg})$ & $75.8 \pm 5.49$ & $77.6 \pm 10.85$ & $70 \pm 7.83$ & $95 \pm 1.76$ \\
\hline Test group III & EERC $(1000 \mathrm{mg} / \mathrm{kg})$ & $142.6 \pm 10.7 * *$ & $161.4 \pm 2.69 * *$ & $166.6 \pm 1.69 * *$ & $151.2 \pm 28.27 * *$ \\
\hline
\end{tabular}

$\mathrm{n}=10$, values are mean \pm S.E.M, One-way ANOVA followed by post hoc Tukey HSD, $* \mathrm{p} \leq 0.05$ significant $\& * * \mathrm{p} \leq 0.005$ highly significant with respect to control. EERC: Ethanol extract of Raphanus caudatus

Table 5. Effect of EERC and diazepam on the time spent on rotarod in Rotarod Test.

\begin{tabular}{|c|c|c|c|c|c|}
\hline \multirow{2}{*}{ Groups } & \multirow{2}{*}{ Treatment } & \multicolumn{4}{|c|}{ Time spent on rotarod without falling (seconds) } \\
\cline { 3 - 6 } & & $7^{\text {th }}$ day & $15^{\text {th }}$ day & $30^{\text {th }}$ day & $60^{\text {th }}$ day \\
\hline Control & Normal saline $(1 \mathrm{~mL} / \mathrm{kg})$ & $271.2 \pm 4.5$ & $277.4 \pm 5.3$ & $280.6 \pm 5.34$ & $284.2 \pm 8.08$ \\
\hline Standard & Diazepam $(1 \mathrm{mg} / \mathrm{kg})$ & $155.6 \pm 7.64^{* *}$ & $138.2 \pm 3.38^{* *}$ & $131.8 \pm 2.58^{* *}$ & $103.2 \pm 1.83^{* *}$ \\
\hline Test group I & EERC $(250 \mathrm{mg} / \mathrm{kg})$ & $265.4 \pm 1.94$ & $263 \pm 2.21$ & $268.2 \pm 8.14$ & $264 \pm 9.24$ \\
\hline Test group II & EERC $(500 \mathrm{mg} / \mathrm{kg})$ & $242.6 \pm 9.67$ & $244 \pm 9.31$ & $259.6 \pm 11.89$ & $253.2 \pm 18.44$ \\
\hline Test group III & EERC $(1000 \mathrm{mg} / \mathrm{kg})$ & $245.4 \pm 18.38$ & $258 \pm 28.61$ & $252.2 \pm 15.26$ & $241 \pm 7.08$ \\
\hline
\end{tabular}

$\mathrm{n}=10$, values are mean \pm S.E.M, One-way ANOVA followed by post hoc Tukey HSD, *p $\leq 0.05$ significant $\& * * \mathrm{p} \leq 0.005$ highly significant with respect to control. EERC: Ethanol extract of Raphanus caudatus 
stituents (flavonoids, alkaloids and steroids) have been reported to possess hypnotic characteristics. These compounds mainly work through GABA-A transmission in the central nervous system (19-21). Moreover, other mechanisms are also reported such as enhanced neuronal $\mathrm{K}+$ conductance, glutamate antagonism, melatonin agonist, orexin antagonist, etc. The current study on animal models indicated sedative-hypnotic potential of EERC and diazepam at different days of testing. Besides, it is observed that the sedative effect after 60-day treatment was more remarkable as compared to other testing days. It might be due to the reason that chronic administration of extract and diazepam produced a potent sedative effect. As it has been evident in previous studies that pronounced effects of Sedative-hypnotic agents were observed after the use of around 2 months (22). Similarly, another study indicated improvement in sleep by benzodiazepines after administration of 24 weeks (long term use) (23). Thus it can be speculated that EERC might produce its sedative effect prominently in the long term use. However, this remains speculation until further studies are conducted for understanding the pros and cons of this effect along with its exact neuropharmacological mechanism that might include GABA receptors, 5HT receptors, noradrenergic / dopaminergic systems, iNOS expression, and brain biogenic amines, etc.

Rotarod is a classical model to evaluate neuromuscular blockade and effect on motor coordination (24). Our results clearly suggest that EERC did not disturb general movement coordination at anxiolytic-effective doses; in other words, EERC lack muscle-relaxant effect suggesting that the anxiolytic effect of the extract might not be due to peripheral neuromuscular blockade, but rather, the central inhibitory mechanism was involved. In addition, present results of rotarod test support the finding that the sedative effects of EERC were due to the central sedative effects rather than peripheral movement inhibition.

\section{CONCLUSION}

The findings of the present study indicate that the ethanol extract of Raphanus caudatus exhibited significant sedative activity in mice. Moreover, the extract was found to be lacking in aberrant muscle relaxation properties. Thus, our study proposes the role of this underutilized and underestimated vegetable in the diet. Furthermore, it may possibly be used as a valuable source of bioactive constituents with psychosedative properties. However, the iden- tification of chemical constituents of the plant along with mechanism(s) of action of plant extract is needed to establish safe and effective psychopharmacological agent/s from the plant extract.

\section{Acknowledgments}

Authors wish to appreciate the Department of Pharmacology, the University of Karachi for providing facilities during this research work. One of the authors acknowledges the moral and financial support of her husband M. Imran Yousuf during this study.

\section{Conflict of interest}

Authors declare that they have no conflict of interest.

\section{Approval of project and ethical clearance}

The whole research protocol as well as ethical clearance was approved by the Board of Advanced Studies \& Research (BASR), University of Karachi (02419/Pharm). The animals used in the study were handled as per specifications described in Helsinki Resolution 1964.

\section{REFERENCES}

1. Slavin J.L., Lloyd B.: Adv. Nutr. 3, 506 (2012).

2. Boeing H., Bechthold A., Bub A., Ellinger S., Haller D. et al.: Eur. J. Nutr. 51, 637 (2012).

3. Hanif R., Iqbal Z., Iqbal M., Hanif S., Rasheed M.: J. Agric. Biol. Sci. 1, 18 (2006).

4. Flyman M., Afolayan A.: S. Afr. J. Bot. 72, 492 (2006).

5. Ali M., Tsou SC.: Food Policy 22, 17 (1997).

6. Khattak K.F.: Pak. J. Pharm. Sci. 24, 277 (2011)

7. Younus I., Siddiq A.: Afr. J. Tradit. Complement. Altern. Med. 14, 142 (2017).

8. Gutiérrez R.M.P., Perez R.L.: Sci. World J. 4, 811 (2004).

9. Okoduwa S.I.R., Umar I.A., James D.B., Inuwa H.M., Habila J.D.: World J. Diabetes 7, 605 (2016).

10. Siddiq A., Younus I.: Metab. Brain. Dis. 33, 1255 (2018).

11. Nugroho A., Kim M.H., Choi J., Baek N.I., Park H.J.: Arch. Pharm. Res. 35, 1403 (2012).

12. Liao Y.J., Zhai H.F., Zhang B., Duan T.X., Huang J.M.: Planta Med. 77, 416 (2011).

13. Jassim S., Naji M.A.: J. Appl. Microbiol. 95, 412 (2003). 
14. Sangthong S., Weerapreeyakul N., Lehtonen M., Leppanen J., Rautio J.: J. Funct. Foods 3, 237 (2017).

15. Beevi S.S., Mangamoori L.N., Gowda BB.: Nat. Prod. Res. 26, 557 (2012).

16. Takaya Y., Kondo Y., Furukawa T., Niwa M.: J. Agric. Food Chem. 51, 8061 (2003).

17. Somers G.: Br. J. Pharmacol. Chemother. 15, 111 (1960).

18. Katzung B.G., Masters S.B., Trevor AJ.: Basic Clin. Pharmacol. (LANGE Basic Science), McGraw-Hill Education 2012.

19. Medina J.H., Viola H., Wolfman C., Marder M., Wasowski C. et al.: Neurochem. Res. 22, 419 (1997).
20. Aguirre-Hernández E., González-Trujano M.E., Terrazas T., Santoyo J.H., Guevara-Fefer P.: Salud Ment. 39, 37 (2016).

21. Hosein Farzaei M., Bahramsoltani R., Rahimi R., Abbasabadi F., Abdollahi M.: Curr. Top. Med. Chem. 16, 1924 (2016).

22. Adam K., Adamson L., Brezinova V., Hunter W.M.: Br. Med. J. 1, 1558 (1976).

23. Oswald I., French C., Adam K., Gilham J.: Br. Med. J. (Clin. Res. Ed.) 284, 860 (1982).

24. Dunham N., Miya T.: J. Pharm. Sci. 46, 208 (1957).

Received: 19.11.2018 